\title{
Correction to: Weight stigma experiences and self-exclusion from sport and exercise settings among people with obesity
}

\author{
Hendrik K. Thedinga ${ }^{1,2^{*}}$, Roman Zehl ${ }^{3}$ and Ansgar Thiel ${ }^{1,2}$
}

\author{
Correction to: BMC Public Health 21, 565 (2021) \\ https://doi.org/10.1186/s12889-021-10565-7
}

It was highlighted that the original article [1] contained some minor reference and typesetting errors in the Background section. This Correction article shows the incorrect and correct references and citations in the sentences. The original article has been updated.

\section{Incorrect}

More regularly, "day-to-day discrimination [ ...] comes in the form of "micro-aggressions" such as [...] misguided comments" ([11] p.n.p.), rude and offensive remarks [9].

\section{Correct}

More regularly, "day-to-day discrimination [...] comes in the form of "micro-aggressions" such as [...] misguided comments" ([10] p.n.p.), rude and offensive remarks [9].

\section{Incorrect}

They regularly encounter "negative weight-related attitudes and beliefs demonstrated by stereotypes, rejection and prejudice" ([16] p.347).

\section{Correct}

They regularly encounter "negative weight-related attitudes and beliefs that are manifested by stereotypes, rejection and prejudice" ([16] p.347).

Finally, with regard to reference [10], the link provided in the original reference was outdated. The correct URL for reference 10 is: https://www.apa.org/topics/racism- bias-discrimination/types-stress. The reference has been updated.

\section{Author details}

${ }^{1}$ Institute of Sport Science, Eberhard Karls University Tübingen, Tübingen, Germany. ${ }^{2}$ Interfaculty Research Institute for Sport and Physical Activity, Eberhard Karls University Tübingen, Tübingen, Germany. ${ }^{3}$ Institute of Sport Science, University of Bern, Bern, Switzerland.

Published online: 25 May 2021

References

1. Thedinga, et al. Weight stigma experiences and self-exclusion from sport and exercise settings among people with obesity. BMC Public Health. 2021; 21:565. https://doi.org/10.1186/s12889-021-10565-7.

9. Thiel A, John JM, Carl J, Thedinga HK. Weight stigma experiences and physical (in)activity: a biographical analysis. Obes Facts. 2020;13(3):386-402 https://doi.org/10.1159/000507936.

10. APA. Discrimination, what it is, and how to cope: American Psychological Association; 2019. Available from: https://www.apa.org/topics/racism-biasdiscrimination/types-stress.

11. Lewis S, Thomas SL, Blood RW, Castle DJ, Hyde J, Komesaroff PA. How do obese individuals perceive and respond to the different types of obesity stigma that they encounter in their daily lives? A qualitative study. Soc Sci Med. 2011;73(9):1349-56. https://doi.org/10.1016/j.socscimed.2011.08.021.

16. Puhl RM, Moss-Racusin CA, Schwartz MB, Brownell KD. Weight stigmatization and bias reduction: perspectives of overweight and obese adults. Health Educ Res. 2008;23(2):347-58. https://doi.org/10.1093/her/ cym052.

The original article can be found online at https://doi.org/10.1186/s12889021-10565-7.

* Correspondence: hendrik.thedinga@uni-tuebingen.de

1 Institute of Sport Science, Eberhard Karls University Tübingen, Tübingen, Germany

${ }^{2}$ Interfaculty Research Institute for Sport and Physical Activity, Eberhard Karls University Tübingen, Tübingen, Germany

Full list of author information is available at the end of the article

(c) The Author(s). 2021 Open Access This article is licensed under a Creative Commons Attribution 4.0 International License which permits use, sharing, adaptation, distribution and reproduction in any medium or format, as long as you give appropriate credit to the original author(s) and the source, provide a link to the Creative Commons licence, and indicate if changes were made. The images or other third party material in this article are included in the article's Creative Commons licence, unless indicated otherwise in a credit line to the material. If material is not included in the article's Creative Commons licence and your intended use is not permitted by statutory regulation or exceeds the permitted use, you will need to obtain permission directly from the copyright holder. To view a copy of this licence, visit http://creativecommons.org/licenses/by/4.0/. The Creative Commons Public Domain Dedication waiver (http://creativecommons.org/publicdomain/zero/1.0/) applies to the data made available in this article, unless otherwise stated in a credit line to the data. 